\title{
Structure of Asclepias syriaca L. population against phytocenotic and habitat conditions in Widuchowa (West Pomerania)
}

\author{
Wanda Bacieczko* \& Agnieszka Borcz
}

Department of Meteorology and Landscape Architecture, West Pomeranian University of Technology in Szczecin, Papieża Pawła VI 3A, 71-459 Szczecin, Poland

* corresponding author (e-mail: Wanda.Bacieczko@zut.edu.pl)

\begin{abstract}
Asclepias syriaca L. is on the invasive species list in Poland. Its sites are scattered, with the exception of cultivation sites; they are also not well identified in the country and that is why they have not been presented in the ATPOL (Distribution Atlas of Vascular Plants in Poland) yet. In this study, spatial structure of $A$. syriaca population against phytocenotic and soil conditions in Widuchowa (West Pomerania) were examined. Number of specimens, their density per $1 \mathrm{~m}^{2}$, and mean crowding were determined. In addition, the population spatial structure type was identified through observations and by calculation of the dispersion coefficient. On the basis of the conducted research, it was found that the investigated population comprised 1500 specimens and occupied the area of $38 \mathrm{~m}^{2}$. It exhibited regular spatial distribution type (dispersion coefficient $<1$ ) and was characterized by high value of mean shoot density, which amounted to 29 spec. $/ 1 \mathrm{~m}^{2}$ (max. $\left.35 \mathrm{spec} . / 1 \mathrm{~m}^{2}\right)$. On the basis of the conducted chemical analysis of the soil from the $A$. syriaca habitat, the substrate was classified as alkaline soil $(\mathrm{pH}=7.3-7.6)$, of low total nitrogen $(0.07-0.15 \%)$, as well as low total carbon content $(0.8-1.45 \%)$.
\end{abstract}

Key words: Asclepias syriaca, anthropophyte, invasive species, population

\section{Introduction}

The Asclepias genus includes over 100 species growing in North America (Woodson 1954). Four of them were recorded in Poland and included: A. incarnata L., A. speciosa Torr., A. syriaca L. and A. tuberose L. (Pogorzelec 2006). Because of their interesting flower structure and high honey production, they are grown as ornamental plants or in bee-gardens. Common milkweed (A. syriaca) has become the best-acclimatized species among them. However, its sites are not numerous, not all of them have been recorded yet and, therefore, they have not been shown in the ATPOL - Distribution Atlas of Vascular Plants in Poland yet (Zając \& Zając 2001).

The interest in common milkweed is increasing because of possibilities of its use in biofuel production (Roşu et al. 2011). The described plant is also rubber-yielding; it contains up to $10 \%$ of rubber (Sudnik-Wójcikowska 2011).
Earlier world scientific reports regarding A. syriaca referred to seed germination process in different aspects (Baskin \& Baskin 1977; Bhowmik 1978; Farmer et al. 1986) - nectar production, and honey production - that is nectar role in pollen germination process (Southwick 1983; Kevan et al. 1989; Farkas \& Zajácz 2007). The issue of interdependence between insects and common milkweed was described in various publications (Morse \& Fritz 1983; Malcolm et al. 1989; Hughes \& Bazzaz 1997; Zalucki \& Malcolm 1999; Fordyce \& Malcolm 2000; Van Zandt \& Agrawal 2004a, 2004b; Agrawal 2005; Delaney et al. 2008; Smith et al. 2008). Some studies concerned its ecology, pollination evolution, and propagation (Sparrow \& Pearson 1948; Morse \& Fritz 1983; Kahn \& Morse 1991; Wyatt \& Broyles 1994). Research was also conducted on A. syriaca defense systems against herbivores (Agrawal \& Fishbein 2006; Bingham \& Agrawal 2010; Rasmann et al. 2011). Furthermore, scientists were also interested in the species genetic structure (Kabat et al. 2010) and in 
chemical substances contained in different parts of the plant (Vaughan 1979).

Few examinations concerning common milkweed were carried out in Poland. The conducted studies concerned isolation, qualitative and quantitative evaluation of different chemical constituents contained in leaves, flowers, and seeds of $A$. syriaca. Those substances can be used for therapeutic purposes (Sikorska et al. 2000, 2001; Sikorska \& Matławska 2000). Other investigations were performed on its flowering, nectar production, and flower attractiveness for insects, which is important in apiculture. Some records of common milkweed occurrence in anthropogenic habitats in Poland are found in geobotanical studies (e.g. Sowa \& Warcholińska 1994; Kucharczyk 2001; Pacyna 2004; Urbisz \& Urbisz 2006; Wrzesień 2006; Nobis 2007; Czarna 2009; Tokarska-Guzik et al. 2011); however, its biology (systematics, morphology, and distribution) was more precisely described by Bacieczko et al. (2013) and Puchałka et al. (2013).

According to the Regulation of the Minister of Environment of the $9^{\text {th }}$ September 2011 (Regulation 2011), A. syriaca is on the invasive species list (Annex 1). That species comes from eastern part of North America and it was brought to Poland in the $18^{\text {th }}$ century. According to geographic-historical classification accepted in Poland (Kornaś 1977a, 1977b, 1981; Sudnik-Wójcikowska \& Koźniewska 1988; SudnikWójcikowska 2011), that taxon is a kenophyte and is characterized by the status of established and potentially invasive plant.

The aim of the research project was to determine phytosociological and edaphic conditions of $A$. syriaca population occurrence in Widuchowa (West Pomerania) as well as to examine and define the type of its spatial structure and vitality of its specimens.

\section{Material and methods}

Asclepias syriaca population was recorded in Widuchowa commune, in Gryfino district (West Pomeranian Voivodeship). It occupies the area of about 1 650 square meters, near an asphalt road leading from Widuchowa in the direction of Lubiczyn. That species was introduced by farmers, who took up beekeeping and used common milkweed as a plant of high honey production.

The examined object is situated in AC 12 square according to ATPOL cartographic system (Zając \& Zając 2001) and it is situated in the mesoregion of Myślibórz Lakeland according to Kondracki (2011). The evaluated common milkweed population is situated on uneven terrain with mild slope (to 10 degrees), slanting in north-western direction. The population area extends from a forest with dominating Scots pine
(Pinus sylvestris L.) in the west to agricultural fields in the east, and from dry grasslands in the north to an asphalt road in the south.

Studies on common milkweed population were conducted in the growing season of 2013. They consisted of the research object recognition with regard to floristic and phytosociological considerations. Phytosociological relevés were made in selected plots according to the Braun-Blanquet method (1951). The modified coverabundance scale of Barkman et al. (1964) was used to estimate species cover. The relevés are shown in Table 1. For each species, its constancy (S) and coverage index (Ic) was calculated according to the following formula (Pawłowski 1959):

$$
I_{c}=\frac{S}{n} \times 100
$$

where: $\mathrm{S}$ - total of means of coverage of each species in all relevés in the table, in which this species is present, $\mathrm{n}$ - number of relevés in the table.

Plant species nomenclature follows Mirek et al. (2002) and syntaxonomical nomenclature was adopted after Matuszkiewicz (2011). The type of population spatial structure was defined on the basis of shoot distribution in the examined area and on the basis of dispersion coefficient calculation according to Trojan (1975). This coefficient $(\mathrm{Cd})$ reached the following values: $\mathrm{Cd}<1-$ regular type of spatial distribution, $\mathrm{Cd}=1$ - random type of spatial distribution, $\mathrm{Cd}>1$ - clustered type of spatial distribution. Population size and shoot concentration per 1 square meter were also estimated and average overcrowding, expressed in Lloyd coefficient value (Collier et al. 1978) was determined. Lloyd coefficient indicates with how many - on average - other specimens each specimen shares its square. Precise geographic coordinates were given by means of manual GPS receiver for each research square and for five chosen plots where phytosociological relevés were made.

To determine edaphic conditions of the evaluated population, four soil samples were taken from the rhizosphere layer (where plant rhizome was growing) using the Egner's soil stick. Then dried soil material was delivered to the laboratory of the Regional Chemical and Agricultural Station in Szczecin to conduct physical and chemical analysis. Soil reaction $\left(\mathrm{pH}_{\mathrm{KC}}\right)$ was determined in the laboratory according to potentiometric method with potassium chloride $(\mathrm{KCl})$ solution of concentration $\mathrm{C}(\mathrm{KCl})=1 \mathrm{~mol} \cdot \mathrm{dm}^{-3}$. Calcium carbonate content was determined according to the Scheibler method and carbon content was determined according to the Turin method. Total nitrogen content was determined according to the Kjeldahl method. Digestible potassium forms $\left(\mathrm{K}_{2} \mathrm{O}\right)$ were determined by means of flame photometry method according to PN-R-04022:1996 standard, and digestible phosphorus $\left(\mathrm{P}_{2} \mathrm{O}_{5}\right)$ was determined with the 
Table 1. Phytosociological structure of the community with Asclepias syriaca L.

\begin{tabular}{|c|c|c|c|c|c|c|c|}
\hline Number of relevé & 1 & 2 & 3 & 4 & 5 & & \\
\hline Latitude [N] & $53^{\circ} 07^{\prime} 42.3^{\prime \prime}$ & $53^{\circ} 07^{\prime} 42.5^{\prime \prime}$ & $53^{\circ} 07^{\prime} 42.6^{\prime \prime}$ & $53^{\circ} 07^{\prime} 43.2^{\prime \prime}$ & $53^{\circ} 07^{\prime} 43.0^{\prime \prime}$ & & \\
\hline Longitude[E] & $14^{\circ} 24^{\prime} 28.3^{\prime \prime}$ & $14^{\circ} 24^{\prime} 28.4^{\prime \prime}$ & $14^{\circ} 24^{\prime} 28.4^{\prime \prime}$ & $14^{\circ} 24^{\prime} 28.6^{\prime \prime}$ & $14^{\circ} 24^{\prime} 27.5^{\prime \prime}$ & & \\
\hline Herbaceous layer cover [\%] & 100 & 100 & 100 & 100 & 100 & $\mathrm{~S}$ & Ic \\
\hline Shrub layer cover $[\%]$ & 0 & 1 & $5 \%$ & 1 & 0 & & \\
\hline Moss layer cover [\%] & 3 & 5 & 3 & 0 & 3 & & \\
\hline Number of species in the relevé & 12 & 19 & 19 & 20 & 18 & & \\
\hline Asclepias syriaca & 4 & 3 & 3 & 3 & 4 & $\mathrm{~V}$ & 4750 \\
\hline \multicolumn{8}{|l|}{ Trees and shrubs } \\
\hline Acer pseudoplatanus b & . & . & 1 & . & . & I & 100 \\
\hline Quercus robur c & . & + & . & + & . & I & 4 \\
\hline Quercus robur b & . & . & + & . & . & $\mathrm{I}$ & 2 \\
\hline Pyrus communis b & . & . & . & + & . & I & 2 \\
\hline Quercus robur c & . & + & . & + & . & I & 4 \\
\hline Acer pseudoplatanus c & . & + & . & . & . & I & 2 \\
\hline Acer negundo c & . & . & . & . & + & I & 2 \\
\hline \multicolumn{8}{|l|}{ Molinio-Arrhenatheretea } \\
\hline Arrhenatherum elatius & $2 \mathrm{~m}$ & $2 \mathrm{~m}$ & 1 & 2 & 2 & $\mathrm{~V}$ & 1500 \\
\hline Dactylis glomerata & $2 \mathrm{~m}$ & . & 1 & 2 & 1 & IV & 900 \\
\hline Calamagrostis epigejos & $2 \mathrm{~m}$ & . & . & 1 & 1 & III & 550 \\
\hline Rumex acetosa & 1 & + & + & 1 & 1 & $\mathrm{~V}$ & 300 \\
\hline Phleum phleoides & . & 1 & 1 & . & 1 & III & 300 \\
\hline Achillea millefolium & . & 1 & . & 1 & 1 & III & 300 \\
\hline Achillea pannonica & . & . & + & + & . & II & 4 \\
\hline Heracleum sibiricum & . & . & . & + & + & II & 4 \\
\hline \multicolumn{8}{|c|}{ Koelerio glaucae-Corynephoretea canescentis } \\
\hline Helichrysum arenarium & . & 1 & 1 & . & . & II & 200 \\
\hline Trifolium arvense & . & + & + & . & . & II & 4 \\
\hline \multicolumn{8}{|l|}{ Festuco-Brometea } \\
\hline Artemisia campestris & . & 1 & . & . & + & II & 102 \\
\hline \multicolumn{7}{|l|}{ Agropyretea } & 4 \\
\hline $\begin{array}{l}\text { Agropyretea } \\
\text { Convolvulus arvensis }\end{array}$ & 1 & . & . & + & + & III & 104 \\
\hline Equisetum arvense & + & + & + & 1 & + & $\mathrm{V}$ & 108 \\
\hline \multicolumn{8}{|l|}{ Trifolio-Geranietea } \\
\hline Galium verum & $2 \mathrm{~m}$ & . & 1 & . & $2 \mathrm{a}$ & III & 800 \\
\hline Astragalus glycyphyllos & . & . & . & . & $2 \mathrm{~m}$ & I & 350 \\
\hline \multicolumn{8}{|l|}{ Others } \\
\hline Festuca trachyphylla & . & 4 & $2 b$ & . & . & II & 1600 \\
\hline Hypericum perforatum & . & + & . & 1 & 1 & III & 202 \\
\hline Vicia hirsuta & . & . & . & 1 & . & I & 100 \\
\hline Melandrium album & + & + & + & + & + & $\mathrm{V}$ & 10 \\
\hline Senecio jacobea & . & . & + & + & + & III & 6 \\
\hline Vicia tetrasperma & + & + & . & . & . & II & 4 \\
\hline Myosotis sylvatica & + & . & . & . & . & $\mathrm{I}$ & 2 \\
\hline Trifolium aureum & . & + & . & . & . & I & 2 \\
\hline Hieracium umbelatum & . & . & + & . & . & $\mathrm{I}$ & 2 \\
\hline Centaurea stoebe & . & . & + & . & . & I & 2 \\
\hline Anchusa officinalis & . & . & . & + & . & I & 2 \\
\hline Cynoglossum officinale & . & . & . & + & . & $\mathrm{I}$ & 2 \\
\hline \multicolumn{8}{|l|}{ Moss layer } \\
\hline Rhytidiadelphus squarrosus & . & + & . & . & + & II & 4 \\
\hline Brachythecium salebrosum & + & . & . & . & . & $\mathrm{I}$ & 2 \\
\hline Calliergonella cuspidata & . & + & . & . & . & I & 2 \\
\hline Hypnum cupressiforme & . & . & $\dot{+}$ & . & . & $\mathrm{I}$ & 2 \\
\hline
\end{tabular}

Explanations: all phytosociological relevés were collected on $8^{\text {th }}$ July 2013 in Widuchowa, on a slope of $10^{\circ}$ inclination, area of relevés $25-30 \mathrm{~m}^{2} ; \mathrm{S}-$ constancy class, Ic - coverage index

assistance of spectrophotometric method on the basis of PN-R-04023:1996 standard. Digestible content of magnesium $(\mathrm{Mg})$ was determined according to the spectrophotometric method with titanium yellow, according to PN-R-04020:1994 standard. 


\section{Results}

\subsection{Plant communities}

On the basis of phytosociological relevés from the observation area with $A$. syriaca, it was found that the plant occurred in semi-natural turfy meadow communities of the Molinio-Arrhenatheretea class (Table 1). This species reached the $\mathrm{V}$ constancy degree and was characterized by the highest coefficient of coverage that attained 4750. Arrhenatherum elatius (L.) P. Beav. was a dominating species of outgoing Arrhenatheretum elatioris community. It was also characterized by $\mathrm{V}$ constancy degree (S) in plots; however, its coefficient of coverage Ic was much lower (1500). Among species typical for the Arrhenatheretalia order: Dactylis glomerata L., Achillea millefolium L., and Heracleum sibiricum L. were recorded. Species growing in sandy and xerothermic grasslands of the Koelerio glaucae-Corynephoretea canescentis and Festuco-Brometea classes were recorded in a smaller amount. These included: Helichrysum arenarium (L.) Moench., Trifolium arvense L., Artemisia campestris L. and Petrorhagia prolifera (L.) P. W. Ball \& Heywood. Also high participation of accompanying species was observed within the floristic composition of plots. Among those species, Festuca trachyphylla (Hack.) Krajina was characterized by a high quantity attribute value, and its coefficient of coverage (Ic) achieved 1600 (Relevés 2 and 3 - Table 1).

\subsection{Edaphic conditions}

On the basis of the conducted chemical analyses of the examined soil from plots with $A$. syriaca, it was found that soil reaction ranged from 7.3 to 7.5 and the evaluated soil was classified as slightly alkaline. Such alkaline reaction affected both microorganism development in the soil, and the mineralization process, which was reflected in low accumulation of organic matter and humus in the evaluated samples (Table 2). Organic carbon content in soil is one of the most important indicators of its fertility. The $\mathrm{C}_{\text {org }}$ content of $\mathrm{C}_{\text {org }}$ in the evaluated soil varied from 0.61 to $1.45 \%$. The content of total nitrogen in soil surface levels ranged from 0.07 to $0.15 \%$ indicating that the examined soil was poor in that element. C:N ratio ranged from 7.6 to $11.4 \%$. Differences in that ratio values indicated various rates of mineralization of organic carbon and nitrogen compounds. The content of digestible potassium $\left(\mathrm{K}_{2} \mathrm{O}\right)$, according to IUNG standards, was high and ranged from 16.1 to 21.4 $\mathrm{mg} \bullet 100 \mathrm{~g}-1$ soil, similarly to magnesium content which varied from 5.2 to $8.9 \mathrm{mg} \cdot 100 \mathrm{~g}-1$ soil. The content of digestible phosphorus $\left(\mathrm{P}_{2} \mathrm{O}_{5}\right)$ was determined as low, according to national standards. Its content ranged from 4.7 to $18.2 \mathrm{mg} \cdot 100 \mathrm{~g}-1$ soil (Table 2 ).

\subsection{Group traits}

Population size in the examined area of about 1650 square meters was estimated at 1500 shoots. However, the average density was 29 plants per 1 square meter (35 specimens per 1 square meter at most). On the basis of observations and of the calculated value of dispersion coefficient, it was found that $A$. syriaca population was characterized by a regular type of spatial distribution (dispersion coefficient $<1$ ). Average overcrowding value, expressed as Lloyd's coefficient, amounted to 26.2. This value was only slightly lower than the average concentration.

\section{Discussion}

In Central European countries, e.g. Slovakia and Hungary, Asclepias syriaca covers ruderal and xerothermic sites of several hectares (Valachovič 1987; Csontos et al. 2009), whereas in Poland its populations grow in dozens of dispersed localities where they cover insignificant areas, like the investigated population in the vicinity of Widuchowa (Urbisz \& Urbisz 2006; Wrzesień 2006; Nobis 2007; Czarna 2009; Tokarska-Guzik et al. 2012; Urban \& Wójciak 2012). For the first time, the locality was recorded in 2011 (unpublished data); therefore, it is difficult to evaluate the exact date when the species appeared in the investigated area. Presumably, it was planted in the first half of the $20^{\text {th }}$ century by the owners of a nearby farm, as a melliferous plant.

The investigated population was growing on an insolated slope along a road, in the vicinity of arable land. Hartzler \& Buhler (2000), in their research, also stated that in the USA (Iowa), localities of A. syriaca were

Table 2. Chemical characteristics of rhizosphere of Asclepias syriaca L.

\begin{tabular}{|c|c|c|c|c|c|c|c|c|c|c|}
\hline \multirow[b]{2}{*}{ Samples } & $\mathrm{pH}$ & Organic matter & Humus & $\mathrm{C}_{\mathrm{org}}$ & Total $-\mathrm{N}$ & $\mathrm{CaCO}_{3}$ & $\mathrm{C}: \mathrm{N}$ & $\mathrm{P}_{2} \mathrm{O}_{5}$ & $\mathrm{~K}_{2} \mathrm{O}$ & $\mathrm{Mg}$ \\
\hline & & content $[\%]$ & & & & & & \multicolumn{3}{|c|}{$\begin{array}{l}\text { content of digestible } \\
\text { components }\left[\mathrm{mg} \cdot 100 \mathrm{~g}^{-1} \text { soil }\right]\end{array}$} \\
\hline 1 & 7.5 & 2.47 & 1.38 & 0.8 & 0.07 & 6.9 & $11.4: 1$ & 4.7 & 16.1 & 5.7 \\
\hline 2 & 7.3 & 3.41 & 2.13 & 1.24 & 0.15 & 1.7 & $8.3: 1$ & 15.6 & 17.8 & 5.2 \\
\hline 3 & 7.4 & 3.61 & 2.5 & 1.45 & 0.14 & 2.9 & $10.4: 1$ & 9.9 & 17.0 & 8.9 \\
\hline 4 & 7.6 & 1.79 & 1.04 & 0.61 & 0.08 & 0.2 & 7.6:1 & 18.2 & 21.4 & 6.5 \\
\hline
\end{tabular}


found more frequently near roads, where they accounted for $71 \%$ of all 859 recorded localities. It proves that roads are artificial ecological corridors, which enable a long-range dispersion of diaspores of alien plant species (Tokarska-Guzik et al. 2012). In Poland, the existing populations of $A$. syriaca have island-like distribution which is mostly caused by the intentional introduction of the species to cultivation or accidental spread of its vegetative parts or seeds. The species also occurs in unused arable lands (Hungary), meadows (USA) or deserted vineyards (Hungary, Slovakia) (Hartzler \& Buhler 2000; Csontos et al. 2009; Pauková et al. 2013).

The investigated population of $A$. syriaca covered the area of $1650 \mathrm{~m}^{2}$ and it reached 1500 specimens, with mean density of 29 specimens per $\mathrm{m}^{2}$. Pauková et al. (2013), in their study, claimed considerably lower density. Also Csantos et al. (2009) recorded lower mean density in deserted vineyards $\left(7.4\right.$ specimens per $\left.\mathrm{m}^{2}\right)$ and arable lands (18.1 specimens per $\left.\mathrm{m}^{2}\right)$. Similar values (1.2-8.8 specimens per $\mathrm{m}^{2}$ ) of specimen density were found in North America (Bhowmik \& Bandeen 1976), whereas significantly higher density (45 specimens per $\mathrm{m}^{2}$ ) was recorded by Valachovič (1987) in western Slovakia. Despite intensive growth of the investigated population, it did not reveal a long-distance spontaneous expansion trend, presumably because its spread was limited by the surrounding phytocoenoses. No other A. syriaca localities were found in the vicinity of the population even though, in general, on average, plants of this species produce up to 226 anemochorous seeds (Willson \& Rathcke 1974).

The population was growing in slightly alkaline soil (pH 7.3-7.6). Also Groh (1943) claims that the species prefers alkaline soils in the east of Canada. According to Timmons (1946) and Spurway (1941), however, in North America A. syriaca grows in acidic soils of 4-5 $\mathrm{pH}$. This proves that the species is able to adapt to soils of lower pH (Bhowmik \& Bandeen 1976).
Floristic composition of communities in which A. syriaca was recorded was diverse (Valachovič 1987; Pauková et al. 2013; Puchałka et al. 2013). In the case of the investigated site, the species was found to grow in wasteland, in former meadow communities of the Molinio-Arrhenatheretea class, in which Arrhenatherum elatius, Dactylis glomerata, and Calamagrostis epigejos achieved high degree of coverage. The wasteland was not used for agricultural purposes, nor mowed for more than 20 years. In the study of Valachovič (1987), Asclepias syriaca was found predominately in ruderal communities. In Slovakia, depending on the habitat type, the species was accompanied by: Centaurium erythraea, Rubus fruticosus, Sambucus ebulus, and Verbascum densiflorum - in deserted vineyards, Achillea millefolium, Centaurea jacea, Cichorium intybus, Cirsium arvense, Convolvulus arvensis, and Rubus fruticosus - in meadows and roadsides. Such species composition was also confirmed by the study of Puchałka et al. (2013) conducted in Poland. In A. syriaca localities near Torun, depending on habitat conditions, the species was accompanied by plants from Artemisietea vulgaris, Festuco-Brometea, Koelerio-Corynephoretea, Epilobietea angustifolii, Molinio-Arrhenatheretea, Stellarietea mediae, Phragmitetea, Querco-Fagetea, and Salicetea purpureae classes.

\section{Conclusions}

It is recommended to include the locality with the A. syriaca population near Widuchowa (West Pomerania) in monitoring system. Long-term observations would allow determining whether this invasive species requires introduction of any preventive measuresin order to limit its further spread. The population of A. syriaca in recent years has been an interesting object of scientific research; therefore, the study will be continued.

\section{References}

Agrawal A.2005. Natural selection on common milkweed (Asclepias syriaca) by a community of specialized insect herbivores. Evol. Ecol. Res. 7: 651-667.

Agrawal A. \& Fishbein M. 2006. Plant defense syndromes. Ecology 87(7): 132-149.

Bacieczko W., Winiarska M. \& Baszutska M. 2013. Asclepias syriaca L. z rodziny Asclepiadaceae - ergazjofit we florze Polski. Zbirnik Naukovo-Tehnícnih, 52-58. Lviv.

BASKIN J. \& BASKIN C. 1977. Germination of common milkweed (Asclepias syriaca L.) seeds. Bulletin of the Torrey Botanical Club 104(2): 167-170.
Вношмік P. 1978. Germination, growth and development of common milkweed. Can. J. Plant Sci. 58: 493498.

Bhowmik P. \& BAndeEn J. 1976. The biology of Canadian weeds. 19. Asclepias syriaca L. Can. J. Plant Sci. 56: 579-589.

Bingham R. \& Agrawal A. 2010. Specificity and trade-offs in the induced plant defence of common milkweed Asclepias syriaca to two lepidopteran herbivores. J. Ecol. 98: 1014-1022.

Braun-Blanquet J. 1951. Pflanzensoziologie. 2 Aufl. 631 pp. Springer Verlag, Wien. 
Czarna A. 2009. Rośliny naczyniowe środkowej Wielkopolski. 184 pp. Wyd. Uniw. Przyr. w Poznaniu, Poznań.

Collier B., Cox G., Johanson A. \& Miller P. 1978. Ekologia dynamiczna. 544 pp. PWRiL, Warszawa.

Csontos P., Bózsing E., Cseresnyés I. \& Penksza K. 2009. Reproductive potential of the alien species Asclepias syriaca (Asclepiadaceae) in the rural landscape. Pol. J. Ecol. 57 (2): 383-388.

Delaney K., Haile F., Peterson R. \& Higley L. 2008. Impairment of leaf photosynthesis after insect herbivory or mechanical injury on common milkweed, Asclepias syriaca. Environ. Entomol. 37(5): 1332-1343.

FARKAS Á. \& ZAJÁCZ E. 2007. Nectar production for the Hungarian honey industry. The European Journal of Plant Science and Biotechnology 1(2): 125-151.

Farmer J., Price S. \& Bell C. 1986. Population, temperature, and substrate influences on common milkweed (Asclepias syriaca) seed germination. Weed Science 34(4): 525-528.

Fordyce J. \& MALCOLM S. 2000. Specialist weevil, Rhyssomatus lineaticollis, does not spatially avoid cardenolide defenses of common milkweed by ovipositing into pith tissue. J. Chem. Ecol. 26(12): 2857-2874.

Gron H. 1943. Notes on common milkweed. Sci. Agric. 23 625-632.

HARTZler R. \& Buhler D. 2000. Occurrence of common milkweed (Asclepias syriaca) in cropland and adjacent areas. Crop Protection 19: 363-366.

Hughes L. \& Bazzaz F. 1997. Effect of elevated CO on interactions between the western flower thrips, Frankliniella occidentalis (Thysanoptera: Thripidae) and the common milkweed, Asclepias syriaca. Oecologia 109: 286-290.

Kabat S., Dick C. \& Hunter M. 2010. Isolation and characterization of microsatellite loci in the common milkweed, Asclepias syriaca (Apocynaceae). Am. J. Bot. 97(5): 37-38.

Kahn A. \& Morse D. 1991. Pollinium germination and putative ovule penetration in self andcross pollinated common milkweed Asclepias syriaca. American Midland Naturalist 126(1): 61-67.

Kevan P., Eisikowitch D. \& Rathwell B. 1989. The role of nectarin the germination of pollen in Asclepias syriaca L. Botanical Gazette 150(3): 266-270.

Kondracki J. 2011. Geografia regionalna Polski. Wyd. 2. 441 pp. Wyd. Nauk. PWN, Warszawa.

KoRnAŚ J. 1977a. Wpływ człowieka i jego gospodarki na szatę roślinną Polski - flora synantropijna. In: W. SzAFER \& K. ZARZYCKI (eds.). Szata roślinna Polski, 1, pp. 95-128. Wyd. Nauk. PWN, Warszawa.

Kornaś J. 1977b. Analiza flor synantropijnych. Wiad. Bot. 21(4): 85-91.

KORNAŚ J. 1981. Oddziaływanie człowieka na florę: mechanizmy i konsekwencje. Wiad. Bot. 25(3): 165-182.

KucharczyK M. 2001. Distribution Atlas of Vascular Plants in the Middle Vistula River Valley. 395 pp. UMCS Press Lublin.

Malcolm S., Cockrell B. \& Brower L. 1989. The cardenolide fingerprint of monarch butterflies reared on the common milkweed Asclepias syriaca. Journal of Chemical Ecology 15(3) 231-240.

Matuszkiewicz W. 2011. Przewodnik do oznaczania zbiorowisk roślinnych Polski. In: J. B. FALı́́ski (ed.).
Vademecum Geobotanicum 3, 537 pp. Wyd. Nauk. PWN, Warszawa.

Mirek Z., Piękoś-Mirkowa H., Zając A. \& ZająC M. 2002. Flowering plants and pteridophytes of Poland. A checklist. In: Z. MireK (ed.). Biodiversity of Poland, 1, 442 pp. W. Szafer Institute of Botany, Polish Academy of Sciences, Kraków.

Morse D. \&Fritz R. 1983. Contributions of diurnal and nocturnal insects to the pollination of common milkweed (Asclepias syriaca L.) in a pollen-limited system. Oecologia 60: 190-197.

NoBis M. 2007. Vascular plants of the Western part of the Iłża Foreland (Małopolska upland). Bot. 40: 1-458.

PaCYNA A. 2004. Vascular plants of the Wieliczka Foothills and adjacent part of the Western Carpatians. IB UJ 38: 1-367.

PAuková Ž., KÁderová V. \& BAKAY L. 2013. Structure and population dynamics of Asclepias syriaca L. in the agricultural land. Agriculture (Pol'nohospodárstvo) 59(4): 161-166.

PAwŁowski B. 1959. Skład i budowa zbiorowisk roślinnych oraz metody ich badania. In: W. SzAFER (ed.). Szata roślinna Polski, 2, 237-268 pp. PWN, Warszawa.

Pogorzelec M. 2006. Rośliny miododajne. 192 pp. Wyd. Sądecki Bartnik, Nowy Sącz.

Puchalka R., Rutkowski L. \& Piwczyński M. 2013: Trojeść amerykańska Asclepias syriaca L. w Toruniu i jego okolicach. Acta Bot. Cassub. 12: 5-23.

Rasmann S., Erwin A., Halitschke R. \& Agrawal A. 2011. Direct and indirect root defences of milkweed (Asclepias syriaca): trophic cascades, trade-offs and novel methods for studying subterranean herbivory. J. Ecol. 99: $16-25$.

Regulation 2011. Regulation of the Minister of Environment of 9 September 2011 of the invasive species list. (Dz.U.2011. 210.1260).

Roșu A., Danaila-Guidea S., Dobrinoiu R., Toma F., Roşu D. Sava N. \& Manolache C. 2011. Asclepias syriaca L. - an underexploited industrial crop for energy and chemical feedstock. Romanian Biotechnological Letters Supplement 16(6): 131-132.

Sikorska M. \& MatŁawska I. 2000. Quercetin and its glycosides in the flowers of Asclepias syriaca L. Acta Poloniae Pharmaceutica 57(4): 321-324.

Sikorska M., MatŁawska I., GŁowniak K. \& ZGóRKa G. 2000. Qualitative and quantitative analysis of phenolic acidsin Asclepias syriaca L. Acta Poloniae Pharmaceutica 57(1): 69-72.

SikORSKA M., MatŁaWsKa I. \& FrańSKi R. 2001. Kaempferol and its glycosides in the seeds hair of Asclepias syriaca L. Acta Poloniae Pharmaceutica 58(3): 211-215.

Smith R., Mooney K. \& Agrawal A. 2008. Coexistence of three specialist aphids on common milkweed, Asclepias syriaca. Ecology 89(8): 2187-2196.

Southwick E. 1983. Nectar biologyand nectar feeders of common milkweed, Asclepias syriaca L. Bulletin of the Torrey Botanical Club 110: 324-334.

SowA R. \& WARCholińsKa A. 1994. The list of American flowering plant species established in Poland (kenophytes). Thaiszia - J. Bot. 4: 197-210.

Sparrow F. \& Pearson N. 1948. Pollen compatibility in Asclepias syriaca. Journal of Agricultural Research 77(6): 187-199. 
SPURWAY C. 1941. Soil reaction $(\mathrm{pH})$ preferences of plants. Mich. Agric. Exp. Sta. Special Bull. 906: 34.

SudNik-Wóscikowska B. 2011. Flora Polski. Rośliny synantropijne. 336 pp. Oficyna Wydawnicza Multico, Warszawa.

SudNik-WóJcikowska B. \& Koźniewska B. 1988. The synanthropization of vegetation glossary. $93 \mathrm{pp}$. Wyd. Uniw. Warszaw., Warszawa.

Timmons F. 1946. Studies of the distribution and floss yield of common milkweed (Asclepias syriaca L.) in Northern Michigan. Ecology 27: 212-225.

TOKARSKA-GUZIK B., DAJDOK Z., ZAJĄC M., ZAJĄC A., URBISZ A., Danielewicz D. \& Holdyński C. 2012. Rośliny obcego pochodzenia w Polsce ze szczególnym uwzględnieniem gatunków inwazyjnych. 197 pp. GDOŚ, Warszawa.

TokArska-Guzik B., Dajdok Z., Zając M., Urbisz A. \& DANIELEWICZ W. 2011. Identyfikacja i kategoryzacja roślin obcego pochodzenia jako podstawa działań praktycznych. In: Z. KĄCKI \& E. STEFAŃSKA-KRZACZEK (eds.). Synantropizacja w dobie zmian różnorodności biologicznej. Acta Botanica Silesiaca 6: 23-53.

Trojan P. 1975. Ekologia ogólna. 418 pp. Wyd. Nauk. PWN, Warszawa

URBAN D. \& WÓJCIAK H. 2012. Interesting vascular plant species in the Bug River Valley (Gołębie-Kosmomłoty section). Teka Kom. Ochr. Kszt. Środ. Przyr. 9: 234250.

URBISZ A. \& URBISZ A. 2006. Invasive vascular plant species in the south-western part of the Silesian Upland (south Poland). Biodiv. Res. Conserv. 1-2: 143-146.

Valachovič M. 1987. On coenology of Asclepias syriaca in Záhorskánížina lowland (West Slovakia). Zprávy
Československej Botanickej Společnosti, Praha 22: 59-60.

Van Zandt P. \& Agrawal A. 2004a. Community-wide impacts of herbivore-induced plant responses in milkweed (Asclepias syriaca). Ecology 85(9): 2616-2629.

VAn ZANDt P. \& Agrawal A. 2004b. Specificity of induced plant responses to specialist herbivores of the common milkweed Asclepias syriaca. Oikos.104: 401-409.

VAUGHAN F. 1979. Effect of gross cardiac glycoside content of seeds of common milkweed, Asclepias syriaca, on cardiac glycoside uptake by the milkweed bug Oncopeltus fasciatus. Journal of Chemical Ecology 5(1): 89-100.

Willson M. \& Rathcke B. 1974. Adaptive design of the floral display in Asclepias syriaca L. American Midland Naturalist 92: 47-57.

Woodson R. 1954. The North American species of Asclepias L. Ann. Missouri Botanical Garden 41(1): 1-211.

WrZESIEŃ M. 2006. Kenophytes chorologically related to the habitats of railway grounds in central eastern Poland. Biodiv. Res. Conserv. 1-2: 92-94.

WyAtT R. \& Broyles S. 1994. Ecology and evolution of reproduction in milkweeds. Annual Review of Ecology and Systematics 25: 423-441.

ZajĄC A. \& ZajĄC M. (eds.). 2001. Distribution Atlas of Vascular Plants in Poland. xii+714 pp. Edited by Laboratory of Computer Chorology, Institute of Botany, Jagiellonian University, Cracow.

Zalucki M. \& Malcolm S. 1999. Plant latex and first-instar monarch larval growth and survival on three north American milkweed species. Journal of Chemical Ecology 25(8): 1827-1842. 